\title{
8
}

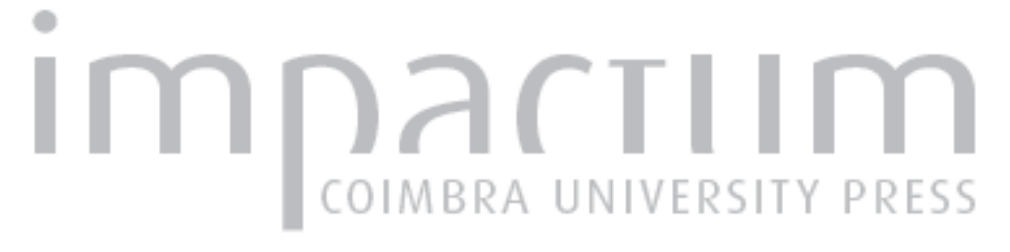

\section{Divindades indígenas da Lusitânia}
Autor(es):
D’Encarnação, José

Publicado por: Imprensa da Universidade de Coimbra

URL persistente:

URI:http://hdl.handle.net/10316.2/45595

DOI:

DOI:https://dx.doi.org/10.14195/1647-8657_26_1

Accessed : $\quad$ 26-Apr-2023 12:06:01

A navegação consulta e descarregamento dos títulos inseridos nas Bibliotecas Digitais UC Digitalis, UC Pombalina e UC Impactum, pressupõem a aceitação plena e sem reservas dos Termos e Condições de Uso destas Bibliotecas Digitais, disponíveis em https://digitalis.uc.pt/pt-pt/termos.

Conforme exposto nos referidos Termos e Condições de Uso, o descarregamento de títulos de acesso restrito requer uma licença válida de autorização devendo o utilizador aceder ao(s) documento(s) a partir de um endereço de IP da instituição detentora da supramencionada licença.

Ao utilizador é apenas permitido o descarregamento para uso pessoal, pelo que o emprego do(s) título(s) descarregado(s) para outro fim, designadamente comercial, carece de autorização do respetivo autor ou editor da obra.

Na medida em que todas as obras da UC Digitalis se encontram protegidas pelo Código do Direito de Autor e Direitos Conexos e demais legislação aplicável, toda a cópia, parcial ou total, deste documento, nos casos em que é legalmente admitida, deverá conter ou fazer-se acompanhar por este aviso.

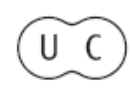


FACULDADE DE LETRAS

INSTITUTO DE ARQUEOLOGIA

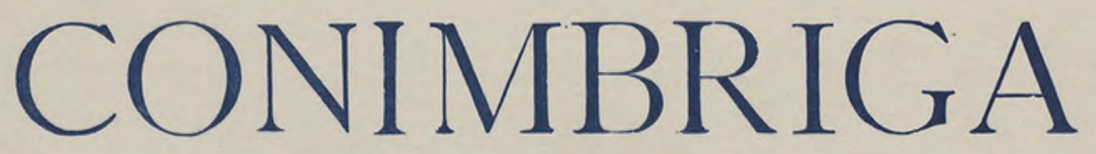

VOLUME XXVI

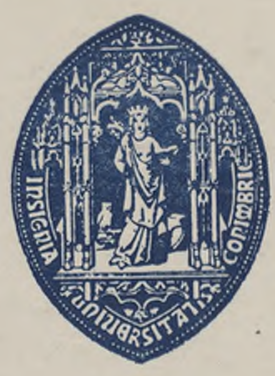

UNIVERSIDADE DE COIMBRA

1987 
Professor associado da Faculdade de Letras de Coimbra

DIVINDADES INDÍGENAS DA LUSITÂNIA

«CONIMBRIGA», XXVI (1987), p. 5-37

Resumo: O autor dá uma panorâmica dos progressos verificados no âmbito da investigação acerca das divindades indígenas: os dados adquiridos, as divindades mais importantes, os problemas em aberto. Inclui, no final, em apêndice, uma lista dos teónimos indígenas documentados na Lusitânia portuguesa.

RÉSUMÉ: L'auteur fait le bilan des progrès vérifiés dans le domaine de la recherche sur le panthéon indigène de la Péninsule Ibérique: les données déjà acquises, les divinités plus importantes, les questions encore à résoudre. En appendice, une liste des théonymes documentés sur les monuments épigraphiques trouvés dans le territoire de la Lusitanie romaine. 
(Página deixada propositadamente em branco) 


\section{DIVINDADES INDÍGENAS DA LUSITÂNIA*}

Quem nunca tivesse ouvido falar em divindades indígenas $\left({ }^{1}\right)$ poderia ter ficado perplexo ao 1er $A$ Voz dos Deuses, de João Aguiar (Lisboa, 1984), dada a variedade de divindades lusitanas que o romance aponta, de culto local e nome rebarbativo. O facto é que João Aguiar tem razão e o seu romance - que bem pode rotular-se de «histórico» ao jeito dum Eurico, de Herculano - dá conta, ainda que envolto nalguma fantasia, do maravilhoso dos Lusitanos que fomos, tal como Leite de Vasconcelos o imaginava no seu tempo $\left(^{2}\right)$.

Não vamos repetir aqui essa imagem nem, mesmo, traçar uma panorâmica exaustiva do panteão lusitano como hoje o conhecemos. Referir-nos-emos, sim, aos progressos verificados neste domínio da investigação histórica: os dados adquiridos, as divindades mais importantes, os problemas em aberto.

A segunda grande tentativa de reunir, num só volume, todos os elementos de que se dispunha para o estudo da religiosidade pré-romana foi feita pelo Prof. José Maria Blázquez Martinez, de Madrid, na sua tese de doutoramento, Religiones Primitivas

* Versão revista e actualizada da comunicação apresentada à Conferência «Os Portugueses e o Mundo» (Porto, Junho de 1985 — cf. «Actas», vol. VI, 1989, p. 103-115).

(1) Sobre o conceito de divindade indígena, cf. a nossa comunicação ao II Congresso Nacional de Arqueologia, Actas, Coimbra, II, 1971, p. 347-351.

$\left.{ }^{2}\right)$ José Leite de Vasconcelos, Religiões da Lusitânia, II, Lisboa, 1905. Cf., ainda, o comentário de J. Manuel Garcia à reimpressão facsimilada desta obra (Imprensa Nacional - Casa da Moeda, Lisboa, 1981) inserto na revista «Prelo» (Lisboa), 2, Jan/Mar 1984, p. 111-119, onde inclusive se dá um

Conimbriga, 26 (1987), 5-37 
de Hispania (Roma, 1962). Blázquez Martínez procurou aplicar, aí, às divindades indígenas, o esquema adoptado para o panteão romano, agrupando-as pelos seus atributos.

Tendo verificado que muito se deduzia a partir de leituras hipotéticas, decidimos, em 1968, repensar o tema e «regressar» aos monumentos ou, na sua ausência, aos manuscritos mais antigos, a fim de confirmarmos a leitura dos teónimos indígenas cujos testemunhos proviessem de território português. Assim poderíamos discretear mais facilmente sobre os atributos dessas divindades estranhas, de que a maior parte das vezes só um testemunho havia e bem avaro de informes.

Então, como hoje, as características das divindades deduziam-se a partir de elementos como: a análise etimológica do seu nome, algum formulário especial do texto, o contexto arqueológico; ou ainda: mediante a sua identificação com um deus romano ou a sua substituição por determinado padroeiro cristão. Assim: atentava-se no significado dos radicais indoeuropeus $\left({ }^{3}\right)$, comuns a

apanhado da investigação posterior a José Leite de Vasconcelos. A obra mais recente que conhecemos é Manifestaciones Religiosas en la Lusitania, editada em 1986 pela Universidade de Extremadura (Cáceres), que reúne as comunicações apresentadas às primeiras jornadas sobre o tema realizadas em Março de 1984. Inserem-se no âmbito das religiões indígenas: Sincretismo en la Lusitania Romana (p. 7-14), de J. M. Blázquez, breve recapitulação do que tem escrito; La Religion de los Pueblos Preromanos de Lusitania (p. 31-49), uma reflexão de Javier de Hoz; Teónimos Indígenas en el S. O. Cacereño (p. 85-92), panorâmica-síntese elaborada por Julio Esteban Ortega; Nueva Evidencia sobre el Culto de Ategina: el Epigrafe de Rienvenida (p. 93-112) onde, a propósito de urna nova ara, Raquel Lopez Melero faz o ponto da investigação acerca desta divindade; Genius Turgalensis (p. 127-132) é pretexto para José M. Iglésias Gil apresentar uma síntese sobre os testemunhos peninsulares do culto ao Génio.

(3) Discutem alguns investigadores a validade deste critério etimológico (cf. o citado trabalho de J. de Hoz, p. 33-34), mormente porque são escassos os nossos conhecimentos acerca das línguas pré-romanas e sua eventual variedade. No entanto, ele é aceite, de um modo geral, como hipótese de trabalho válida. Recordemos que foi $\mathrm{F}$. Adolfo Coelho um dos primeiros filólogos a debruçar-se sobre o tema: em 1880, apresentou em Lisboa ao IX Congresso Nacional de Antropologia e Arqueologia Pré-Históricas, uma comunicação intitulada Sur les cultes péninsulaires antérieurs à la domination romaine (Actas, p. 438-449).

Conimbriga, 26 (1987), 3-37 
todas as línguas ocidentais, partindo do pressuposto de que estes se tinham conservado quase intactos nos teónimos (apenas) latinizados; uma invocação pro salutem indiciava um deus benfazejo; a proximidade de fonte termal postulava uma divindade das águas; a identificação com Marte só era possível a um deus com as mesmas características bélicas; a sua substituição por S. Miguel, padroeiro das almas do Além, era sinónimo dum deus infernal.

Foram os resultados dessa pesquisa que defendemos, como tese de licenciatura, em Janeiro de 1970. E a Imprensa Nacional houve por bem publicá-los posteriormente, em 1975, com leves alterações e alguns aditamentos, sob o título Divindades Indigenas sob o Domínio Romano em Portugal.

Nesse mesmo ano, apresentava J. Maria Blázquez, sob a forma de dicionário (exactamente como nós concebêramos o nosso volume), uma síntese do seu primeiro trabalho, actualizada $\left({ }^{4}\right)$.

O tema alcançou, desta sorte, alguma popularidade, de maneira que outros investigadores por ele se interessaram.

A nossa intenção fora só, como dissémos, a de procurar 1er bem os teónimos e avançar com hipóteses interpretativas desde que para tal houvesse uma base concreta. Lembrávamo-nos da solidez dos trabalhos de Scarlat Lambrino - um mestre na análise da teonímia indígena $\left(^{5}\right)$ - tínhamos presentes as numerosas conjecturas lançadas até aí, sem fundamento. Importava 1er correctamente, acentuar bem o que era duvidoso. Várias vezes nos fixámos em oposição a José Maria Blázquez - mas a metodologia utilizada viria a dar, pouco a pouco, os seus almejados frutos.

No seu Portugal Romano, designadamente na $3 .^{\text {a }}$ edição, de 1983 (p. 177-180), Jorge Alarcão apresentou uma cautelosa síntese do que de mais relevante se conhecia das divindades indígenas. A pressão editorial dos últimos tempos (hoje, a ânsia de grandes volumes de síntese não deixa tempo para aprofundada análise), aliada ao grande incremento da investigação, levou o

(4) Diccionario de las Religiones Prerromanas de Hispania, Madrid, 1975.

(5) A Scarlat Lambrino se devem sólidos trabalhos sobre Endovélico, Trebaruna, o santuário de Panóias. Ver bibliografía em Eduardo Pires Oliveira, Bibliografia Arqueológica Portuguesa (1935-1969), 1984, p. 115-116.

Conimbriga, 26 (1987), 5-37 
Prof. Blázquez a publicar Religiones Prerromanas (Ediciones Cristiandad, Madrid, 1983, 566 pág.), obra que dividiu em cinco capítulos: a religião dos Tartéssios, a cultura turdetana, os Iberos, outros povos da Península, o panteão indígena. Relativamente ao que particularmente nos interessa, é incluído no volume um importante índice, da autoria da saudosa Maria de Lourdes Albertos, sobre Teónimos hispánicos (p. 477-488): além do nome da divindade, em dativo, M. L. Albertos dá, de cada urna, a bibliografía fundamental e o local de culto.

Por conseguinte, a lista (digamos assim) está quase feita. Importa, pois, reservar uns tempos para reflexão, a fim de passarmos do quantitativo, da mera enumeração, para o qualitativo: que resultados obtivémos até agora? que panorama da íeligiosidade pré-romana é já possível delinear?

Tem sido relevante, neste dominio, o papel dos epigrafistas portugueses, mormente numa tentativa de clarificação desse panorama. E hoje são já aceites, além da metodologia que preconizamos, algumas das teses que apontámos como válidas.

Assim, afigura-se-nos que é dominante o carácter local — tópico ou étnico - das divindades: daí, por exemplo, a exiguidade de testemunhos; daí, também, o facto de as divindades de invocação geral, como Banda, Reva, Nabia, Arentius, Cosus - cujo culto se não confina a um santuário ou a uma zona determinada (como Endovélico ou Trebaruna) - assumirem epítetos locais. Poderão, inclusive, ser mais frequentemente invocados por esses epítetos: já o apontámos em relação a Cosus Neneoecus, que uma vez se designa apenas Neneoecus; já o supusemos em relação a Banda Toiraecus, invocado em Vila da Feira como Tueraeus; a revisão, recente, a que procedemos, duma ara de Belver, dedicada a Bannei Picio, parece confirmar que o teónimo Picius, documentado em S. Pedro da Lourosa, não será mais do que o epíteto daquela divindade.

Consequentemente, é possível, neste momento da investigação, que o número de divindades do panteão indígena, em vez de aumentar fragmentariamente, tenda a diminuir e a clarificar-se, aproximando-se, quiçá, cada vez mais, das grandes tendências religiosas da Humanidade enquadráveis num esquema indoeuropeu. As descobertas mais recentes apontam, de facto, para uma valorização das divindades de invocação geral atrás mencionadas. 
A existência de locais de culto bem determinados, onde as populações amiúde se reunissem, afigura-se-nos também como uma das ideias fundamentais a reter e a nortear a investigação epigráfica e arqueológica ( ${ }^{6}$ ). Na verdade, as descobertas arqueológicas sucedem-se a um ritmo impressionante: o imponente santuário de Panóias é, agora, apenas um dos vários que se conhecem...

Outro elemento a ter em conta é o da chamada interpretatio, a assimilação das divindades indígenas às divindades romanas. Interessa ser muito sensível à cronologia, buscando, por exemplo, nos dados arqueológicos e nos hábitos antroponímicos elementos passíveis de datar ex-votos e lugares de culto. Não nos parece indiferente saber se foi a divindade romana que se assimilou à indígena ou esta que se assimilou àquela. $\mathrm{O}$ resultado é o mesmo; o processo é, porém, diferente e do maior interesse do ponto de vista cultural e quiçá também político.

E precisamos de reflectir sobre se será justificável continuar a incluir no âmbito das divindades indígenas as divindades romanas (Juno, Júpiter, Marte, Mercúrio), sempre que se apresentem com epítetos localmente individualizáveis (por exemplo, Assaecus, Aguaecus), mormente quando se trata de divindades tutelares do tipo dos Lares, Genius... E se o Génio de Conímbriga se pode considerar sem grandes objecções mais de cariz romano que indígena, Júpiter Repulsor oferece também sérias dúvidas quanto ao seu carácter indígena, se atendermos ao teor bem latino do epíteto, apesar de venerado só numa área da Lusitânia. No apêndice final ainda integramos estes casos, mas isso não significa que, da nossa parte, a discussão esteja encerrada.

Nessa mesma ordem de ideias, deverá continuar a merecer atenta reflexão a ocorrência do culto prestado por indígenas a Júpiter Óptimo Máximo em zonas onde se mantêm pujantes, na mesma época, os cultos pré-romanos $\left({ }^{7}\right)$.

(6) Assinalamo-lo em Omissão dos teónimos em inscrições votivas, «Veleia», 2-3, 1985-1986, p. 305-310.

(7) Cf. José CPENCARNAÇÃo, A religião romana não-oficial nas colónias $e$ municípios da Lusitânia durante o Alto Império, «Memórias de História Antigua», 5, 1981, p. 30-31. 
O aprofundamento dos estudos linguísticos contribuirá, decerto, para clarificar a questão das variantes gráficas dos teónimos: simples «desvio» fonético puramente casual, que se explica, por exemplo, pela ignorância do lapicida ou, ao invés, variante pensada que encontra fundamento em clara diferenciação linguística? Se Tueraeus é uma variante de Toiraecus perfeitamente explicável do ponto de vista gramatical, que mecanismo profundo levou a adoptar uma das designações de preferência a outra? Que factores estarão por detrás do facto de a divindade Banda $\left.{ }^{8}\right)$ umas vezes apresentar o dativo em Bandi, outras em Banda, Bandue, Bandei ou mesmo em Bannei? Mera dificuldade em passar a caracteres latinos aquilo que era uma voz diferente, antes jamais escrita, comum entre os indígenas?

O caso de Endovélico é sintomático, não só pelas variantes (bem documentadas) que a sua designação apresenta e que, pelo

${ }^{8}$ ) Denominamo-lo assim por uma questão de facilidade e por nos parecer que essa poderá ser a designação mais geral. Nada nos garante, porém, que outro não tenha sido o nominativo vulgar deste teónimo. M. L. Albertos $(1975$, p. 53) era de opinião que essas desinências «são restos da declinação indígena, mais ou menos bem adaptada à escrita e à morfologia latina, influenciada também, sem dúvida, pelo latim vulgar cuja apreensão não fora muito perfeita por parte quer dos lapicidas quer dos dedicantes que encomendaram a gravação». E acrescentava: «Se a língua religiosa é sempre, por definição, mais conservadora (...), é normal que, nos nomes dos deuses e nos seus epítetos, como patronos das gentilidades, (...) encontremos desinências e sufixos de estrutura indígena arcaicos e não formas perfeitamente latinas». J. Hoz (1986, p. 36-41) prefere a designação Bandue. Acerca deste teónimo, é de opinião que «Bandue é provavelmene um nome comum do campo religioso lusitano, traduzível por 'divindade' (...); que se usou entre os Lusitanos em sentido estricto e entre os Galaicos da zona entre Douro e Minho; que numa maioria de casos aparece precisado por um epíteto, em geral masculino, às vezes feminino, e que a morfologia das suas desinências parece indicar dificuldades de adaptação ao latim, e inclusive talvez à gramática lusitana cujo carácter indo-europeu é seguro» (p. 39). Mais adiante (p. 41), após afirmar que «se trata de uma divindade protectora e tutelar», escreve: «Não precisamos de pensar que todas as dedicatórias com esta invocação se refiram efectivamente a uma mesma divindade», o que, à primeira vista, poderá parecer um tanto contraditório. Em seu entender, portanto, o epíteto é que seria o verdadeiro teónimo. É opinião assaz discutível esta: parece-nos mais lógico que o elemento Bandue seja nome próprio e que os epítetos tenham carácter adjectival.

Conimbriga, 26 (1987), 5-37 
menos aparentemente, nada têm a ver nem com o nivel cultural dos dedicantes nem com a sua proveniencia étnica ou social $\left({ }^{9}\right)$, mas também, e sobretudo, porque aumenta de dia para dia o número de testemunhos do seu culto $\left({ }^{10}\right)$ e porque nos parece extremamente provável que, de acordo com a opinião de F. Fernández-Gomes $(\mathrm{n})$, além do santuário de S. Miguel da Mota (Terena, Alandroal) - autêntico local de peregrinação das gentes da Lusitânia meridional-, lhe tenham sido consagrados mais dois: o de Cerro Andebalo, perto de Cabezas Rubias, onde a divindade era adorada sob a invocação de Andobelicus ou Endovelus, e o de Postoloboso (Candeleba, Ávila) onde a designação era, simplesmente, Vellicus.

São úteis as listas de teónimos para clarificar ideias. Mas importará, doravante, responder a estas questões.

A relacionação das divindades com os núcleos populacionais que lhes prestavam culto assume-se como urna das perspectivas mais válidas, no actual momento da investigação. Saúdem-se, pois, como sendo do maior interesse as hipóteses justificadamente lançadas por Jorge de Alarcão, na conferência que fez, aquando do I Colóquio Viseense de Arqueologia (Viseu, Abril 1988), subordinada ao título Geografia política e religiosa da civitas de Viseu.

(9) Cf. José d'Encarnação, Inscrições Romanas do Conventus Pacensis, Coimbra, 1984, p. 800-805.

${ }^{10}$ Cf. Manuel J. P. Maciel e Tarcísio D. P. Maciel, A propósito de uma nova ara a Endovélico, «Gaya», 4, 1986, p. 9-18.

(n) In «Noticiário Arqueológico Hispánico. Arqueología», 2,1973, p. 230. $\mathrm{Na}$ comunicação Divindades indígenas peninsulares: problemas metodológicos do seu estudo, que apresentámos, em Maio de 1986, ao Simpósio Internacional de Epigrafia Jurídica «La Tabula Siarensis y su Contexto Historico», em Sevilha (Actas, 1988, p. 261-276), retomámos desenvolvidamente esta problemática. Aí focámos também os casos de Banda, Arentius e Nabia (divindades com epítetos) e de Trebaruna, que, como EndovéJico, é divindade com diferentes grafias do nome.

Conimbriga $_{1} 26$ (1987), 5-37 
Aí aponta, por exemplo, a possibilidade de a divindade Crouga ser tutelar de um castellum Nil[...], devido ao epíteto Nilaicus, e de um castellum Macar[...], devido ao epíteto Macareaicus que apresenta; relaciona - na esteira de M. Lourdes Albertos - o culto a Banda Araugelensis com o castellum de Araocelum, o qual, por seu turno, poderá estar relacionado com os epítetos Ocelaecus (de Arentius) e, porventura, de Banda (se lermos não Bandoga mas Band. Ocel..., na ara do Castro do Mau Vizinho). Como escrevemos no trabalho citado na nota 11 , «a questão que se nos põe é a de saber se poderemos, hoje, ir abandonando a designação pontualmente adoptada de divindade indígena para a substituirmos pela de divindade asturiana, céltica, ibérica, lusitana...». Um salto qualitativo cuja eficácia e segurança só uma estreita colaboração entre epigrafistas, linguistas e arqueólogos poderá efectivamente garantir. 


\section{APÊNDICE}

\section{Teónimos indígenas documentados na Lusitânia portuguesa}

Os teónimos vão em dativo (como aparecem nas epígrafes), por ordem alfabética. Apresenta-se, de cada um, a síntese do que se conhece a seu respeito, remetendo para a bibliografia (que melhor se identifica no final) $\left({ }^{l}\right)$.

\section{Aelua ( ?)}

Divindade de nome um tanto duvidoso e características desconhecidas, a que os castellani ( ?) Berecenses ( ?) dedicaram uma ara em Famalicão da Serra, Guarda (FE 98). Poderá ter relação com o teónimo Alva a que aludimos na nota $1 .{ }^{*}$

(9 Omitimos os casos muito duvidosos :

- Alva[?) : apesar da semelhança com Aelua, não é claro que seja esta a divindade honrada na ara de Mouriscas, Abran tes (FE 2).

- Aponianico Poliscinio: trata-se, de facto, duma dedicatória ao Génio feita por Aponía Nicopolis, como demonstrou J. Untermann (1985, p. 345-6). Ver também J. Gardim Ribeiro in «Veleia», 2-3, 1985-1986, p. 311-325 (artigo reproduzido, com leves alterações, em «Lisboa - Revista Municipal», 2. ${ }^{a}$ série, 20, 1987, p. 3-14.

- Aratibro: afigura-se-nos difícil esta interpretação como teónimo considerada por J. M. Garcia numa ara do concelho de Castelo Branco (1984, p. 45-46).

- Aro: DIP, p. 108-110; Correia 1986, p. 106-109. Concordamos com Untermann (1985, p. 345) : não há justificação para ver aí um teónimo.

- Cubar: DIP, p. 151-152. Cf. também Le Roux 1982, p. 226 (n. 191).

- Dipainciae: pouco provável esta interpretação de J. M. Garcia (1984, p. 53-54). Ara proveniente de Castelo Branco.

- Genius Conimbricae: DIP, p. 188. FC II, p. 24-25. O seu carácter indígena é muito discutível.

- Genius Cor: DIP, p. 189.

- Genius Depenoris: DIP, p. 190.

- Iccona Loiminna: vocábulos que surgem no penedo de Cabeço das Fráguas. Tovar chegou a pôr a hipótese de se tratar dum nome de divindade acompanhado por epíteto, mas acabou por não considerar totalmente viável essa hipótese (1967, p. 254-255).

- Iuno Veamuaearum: DIP, p. 205-206. Cf. também Corominas 1976, p. 376-378; contra: Albertos 1985, p. 504.

Conimbriga, 26 (1987), 5-37 
Aetio

Divindade de características desconhecidas a quem Cisia dedica uma árula, achada em Covão (Alcaria, Fundão).

Vaz 1977, p. 6-7.

\section{Araco Aranto Niceo}

De características desconhecidas, vagamente relacionável com as águas, é divindade honrada por uma indígena romanizada, Júlia Máxuma, filha de Auvo, numa ara achada em Carrascal de Manique (Alcabideche, Cascais). Fig. 1.

DIP, p. 92-97. Catálogo da exposição «Cascais no tempo dos Romanos» (Cascais, Agosto 1986).

\section{Arentio}

Divindade tutelar, que se documenta numa ara encontrada em Chão do Touro (Monsanto, Idanha-a-Nova), mandada gravar por Súnua, filha de Câmalo. DIP, p. 103-104.

Em Ninho do Açor (Castelo Branco), o par divino Arentius e Arentia é homenageado por Montano, filho de Tangino. DIP, p. 101-103; Garcia 1984, p. 49-50.

Cingindo-nos ao território português, temos mais quatro testemunhos do culto a Arentius com epítetos:

- Arentio Cronisensi ( ?), honrado por Albino, filho de Próculo, numa ara procedente de Zebras (Orca, Fundão). DIP, p. 104-106. Fig. 2.

- Mirobieo: está, de facto, no Museu Nacional de Arqueologia e Etnologia (Lisboa) o fragmento do penedo com inscrição, arrancado em Tarouquela (Cinfães). Mantêm-se as dúvidas que apontávamos em 1975:

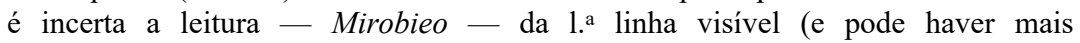
linhas acima) ; esse vocábulo poderá ser apenas um atributo de loco (linha 2) ; não há qualquer fórmula que justifique o carácter votivo atribuído ao texto. DIP, p. 235-237. Cf. Untermann 1980, p. 423. Ver Fig. 10 (p. 35).

- Neto: não dispomos de mais elementos susceptíveis de esclarecer convenientemente o carácter do texto, ainda perdido, dado como proveniente de Conímbriga (Condeixa-a-Velha, Condeixa-a-Nova) e dedicado eventualmente a esta divindade. DIP, p. 248-250; FC II, p. 35-36. 


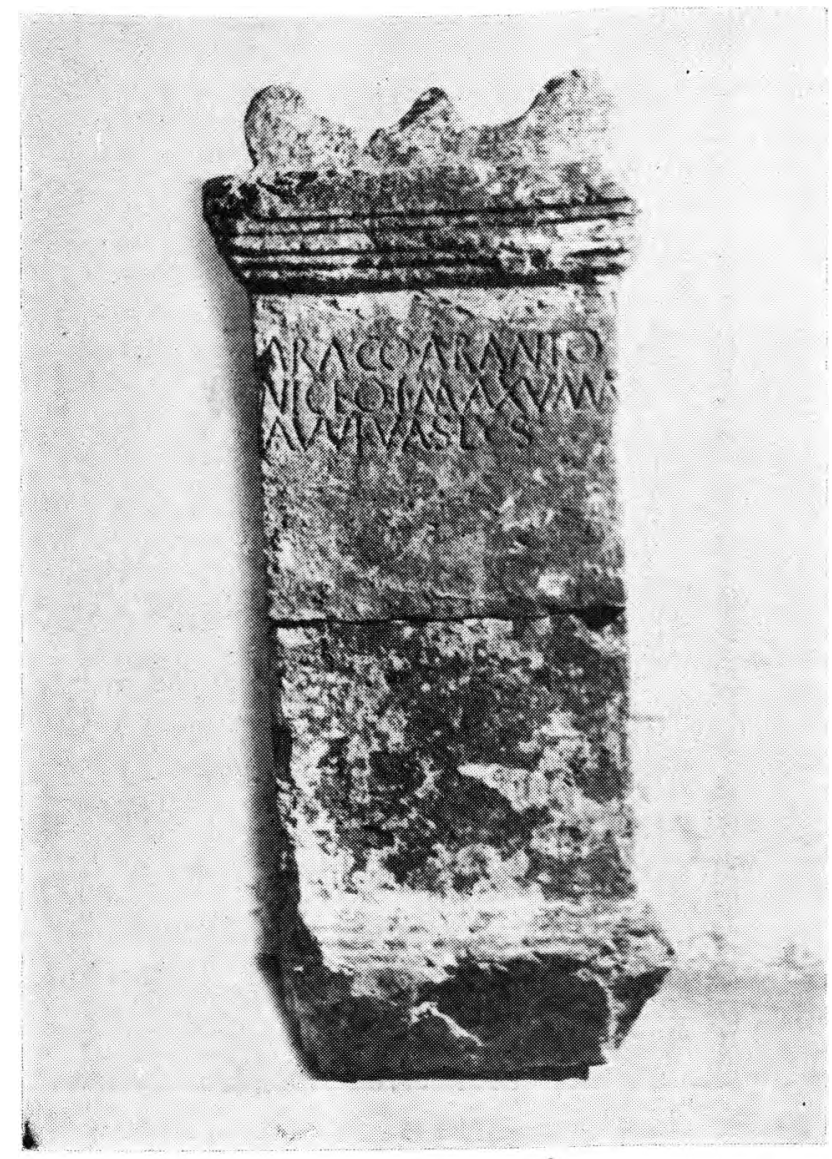

Fig. 1-Ara a Aracus Arantus Niceus

- Arentiae Equotullaicensi, honrada por Níger, filho de Arcão, em Sabugal. FE 27.

- Arantiae Ocelaecae e Arantio Ocelaeco, homenageados por Rufo, filho de Peicano, em Ferro (Covilhã). Albertos 1985, p. 470-4.

- Arantio Tanginiciaeco: a ara, dedicada por Avita, filha de Vitalis, foi encontrada no termo de Rosmaninhal (Idanha-a-Nova). DIP, p. 98-101; Garcia 1984, p. 47-48.

É, pois, um culto territorialmente bem delimitado.

Conimbriga, 26 (1987), 5-37 


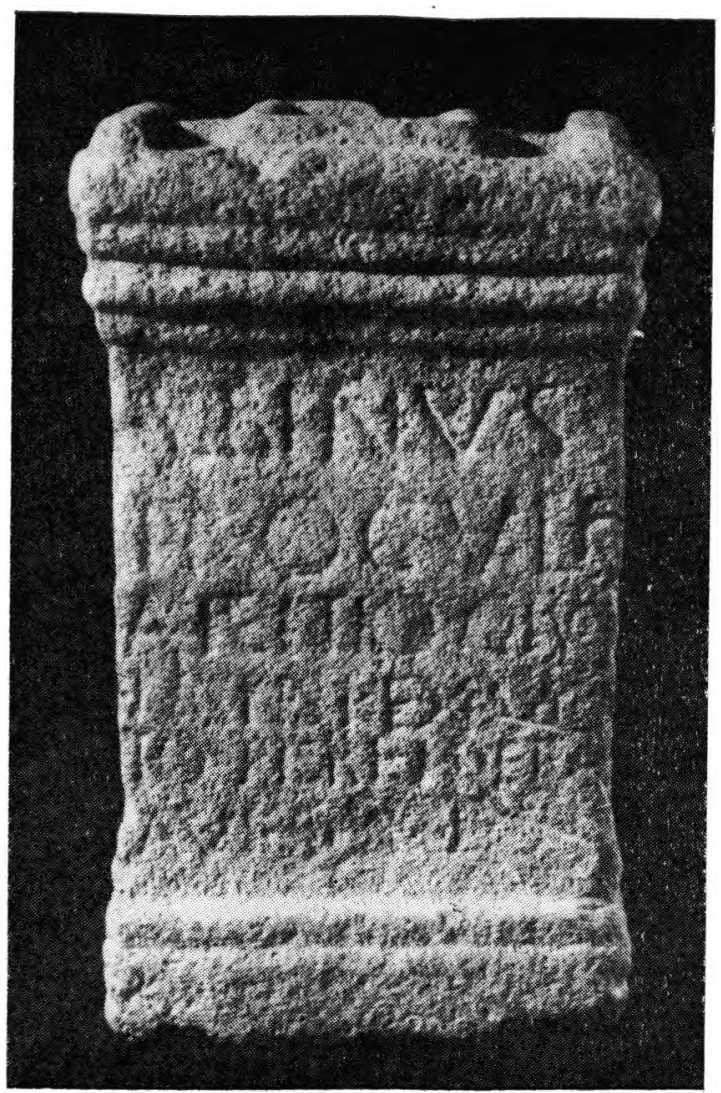

Fig. 2- Ara a Arentius Cronisensis

\section{Ataegina}

0 culto a esta divindade infernal, cujo santuário se devia situar numa localidade de nome Turóbriga, está possivelmente atestado, no território nacional, numa ara (IRCP 287) do termo de Beja, dedicada por L. Axónio, onde a divindade se identificará D(eae) S(anctae) Turubrice(nsi) ; outra ara, de Mértola (IRCP 95), foi dedicada (apenas) Deae Sanctae por C. Valerius Rufus Caepio; no bordo dum vaso, proveniente também do termo de Beja e de que só nos resta um desenho, talvez se possa 1er também Deae Sanctae (IRCP 288). 
IRCP, p. 799-800.

Numa árula do termo de Ouguela (Campo Maior) lê-se, na linha 1, Q.P.R.D.S: o autor da notícia (FE 32) interpretou as três primeiras letras como as siglas do nome do dedicante e, depois, $D$ (eae) S(anctae) subentendendo-se T(urobrigensi). Parece-nos forçado.

Aturro

Divindade de características ctónicas cujo monumento foi encontrado em Lisboa.

DIP, p. 117-118.

\section{* Banda}

São numerosos os epítetos por que esta divindade tutelar é invocada (DIP, p. 140-143), ultrapassando inclusive os limites da Lusitânia ${ }^{2}$ ).

- Bandi Arbariaico: monumento, hoje perdido, procedente de Capinha (Fundão), dedicado por Amino, filho de Andaitia ( ?). DIP, p. 129-131.

- Bandei Brialeacui: ara encontrada em Orjais (Covilhã), dedicada por Severo, filho de Abruno. DIP, p. 125-126. Existe uma outra ara, inédita, procedente da mesma zona, que apresenta igual grafia do teónimo; não está aí bem claro, no entanto, o nome do dedicante (Mantaus?).

- Bandua Etobrico: árula achada, possivelmente, nos arredores de Alenquer. Encarnação 1976, p. 142-144.

- Bandi Isibraiegui: duas aras, de Bemposta (Penamacor)? dedicadas, respectivamente, por Cílio, filho de Câmalo, e por Materno, filho de Melão. DIP, p. 131-132; Leitão 1980, p. 627-631.

- Bandi Longobricu: ara encontrada na capela de N. ${ }^{a} \mathrm{Sr}^{\mathrm{a}}$ do Torrão, em Longroiva (Meda), dedicada por Q. Iulius Montanus,

(2) Omitimos o texto, de Idanha-a-Velha, que segundo D. Fernando de Almeida (1965, p. 23-24) traria Bandi: em nosso entender, está correcta a identificação, que nos foi sugerida por J. M. Garcia, com o monumento onde se lê claramente GENIO ( e não BANDI). 
eques da legião VII Gémina Félix. É evidente a relação Longrobricus/Longroiva. FE 44.

- Band. O... (ex-Bandoge): desconhece-se qual seja exactamente a invocação do deus que vem gravada nesta ara procedente do Castro do Mau Vizinho (S. Pedro do Sul), dedicada por Céltio, filho de Câmalo. Será Ocel(ensi) ou Ocel(aeco)? DIP, p. 138-139; Encarnação 1977, p. 213-214.

- Bandi Oilienaico: fragmento de ara procedente de Esmolfe (Penalva do Castelo). DIP, p. 132-134.

- Bannei Picio (não Ranelpicio): foi-lhe dedicada por Amminus, Taltici (filius), uma ara encontrada em Vale de Mó (Belver, Gavião). Decerto é também em sua honra a outra ara da mesma proveniência que não traz indicação de teónimo, o que pressupõe a existência duma tradição local de culto. Desta sorte, a ara de S. Pedro de Lourosa (Oliveira do Hospital), dedicada por Arco, Mauci filius, a Picio deverá ser incluída aqui: o deus é designado apenas pelo epíteto. DIP, p. 259-261; Encarnação 1984, p. 13-19.

- Bandi Tatibeaicui: ara proveniente de Queiriz (Fornos de Algodres) dedicada, quiçá, por um Q. Vário, filho de Apino. DIP, p. 134-137.

- Bande Velugo Toiraeco: L. Latrius Blaesus dedica, em Vila da Feira, uma ara a esta divindade, que, noutro monumento mandado fazer pelo brácaro Arcius, Epeici filius, vem denominada deo Tueraeo. DIP, p. 128-129 e 291-9.

- Bandi Vorteaeceo: ara, encontrada em Salgueiro (Fundão)» dedicada por Reburrus Tangini (filius). DIP, p. 137-138; Vaz 1977, p. 8-9.

Em Arrochela (Penamacor), foi consagrada uma ara a Vortiaecii (sic) por Flavius Titius Felix. FE 57.

Outra ara, procedente de S. Martinho (Castelo Branco) e de que resta a parte inferior, se lhe atribui também: Garcia 1975, p. 147-159; idem, 1984, p. 79.

É igualmente possível que as siglas B. V. S. da árula de S. Vicente da Beira (Castelo Branco) (Garcia 1984, p. 51) se interpretem B (andi) I(orteaeceo) S (acrum), o que denunciaria até a sua inclusão num santuário. 


\section{Carneo Calanticensi}

0 deus, patrono duma eventual Calantica, cultuado em Santana do Campo (Arraiolos).

Três inscrições: IRCP 410-412 e p. 800. Fig. 3.

\section{Collovesei Caieioni Cosigo}

Torna-se difícil - sem o achamento de outros paralelos saber qual a divindade identificada com estas palavras, à qual Pudens, Competri (filius) consagra uma ou várias aras. Regista-se em Furtado (Algodres, Fornos de Algodres).

FE 74.

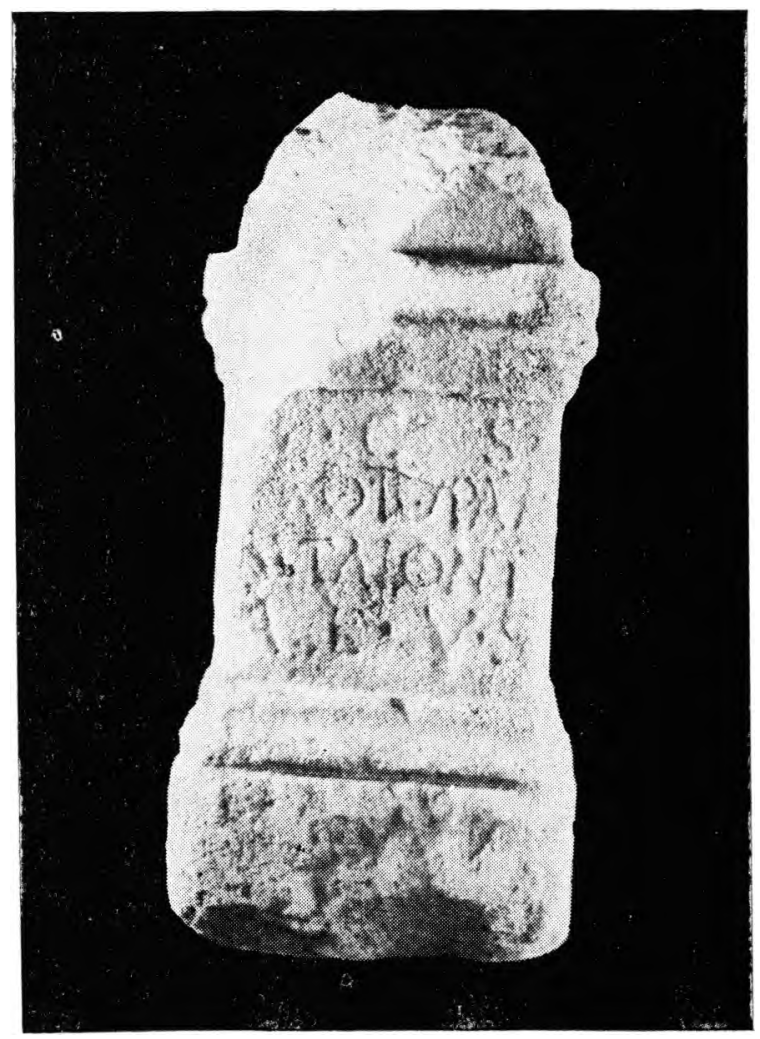

F IG. 3 - A árula verosimilmente dedicada au deus Carneus

Conimbriga, 26 (1987), 5-37 


\section{Crougae Nilaigui}

Divindade de nome incerto (as letras foram avivadas) venerada, ao que parece, por um Clementinus, Cei filius, em Freixiosa (Mangualde).

FE 54.

\section{Crougeai Magareaicoi Petravioi}

Segundo Maria de Lourdes Albertos, Crougeai seria o dativo dum teónimo, aparentado com o anterior (ou de preferência o mesmo), que, no texto do penedo de Lamas de Moledo (Castro Daire), onde surge pela única vez, estaria acompanhado de dois epítetos.

Albertos 1975, p. 58; Correia 1986, p. 101-103.

\section{Cusei Paetaico}

Variante do teónimo Cosus, conhecido de outras inscrições, com um epíteto novo. O ex-voto foi oferecido por Búcio, filho de Turaino (?). Provém de Aguada de Cima (Águeda). Numa árula, exposta em Abril de 1988 no Museu de Grão Vasco (Viseu), sem indicação de proveniência, lê-se Cosei seguido de epíteto (por identificar).

FE 70 e 140.

\section{Dee Sancte Burrulobrigensi}

Patrona duma eventual Burrulobriga, esta deusa vem mencionada numa elegante árula de Eivas. Fig. 4.

IRCP 566.

\section{Dis Deabusque Coniumbricensium}

Divindades homenageadas numa ara achada em Numão (Vila Nova de Foz Côa), por um cavaleiro da III coorte dos Lusitanos.

DIP, p. 175-176. FC II, p. 21-22. 


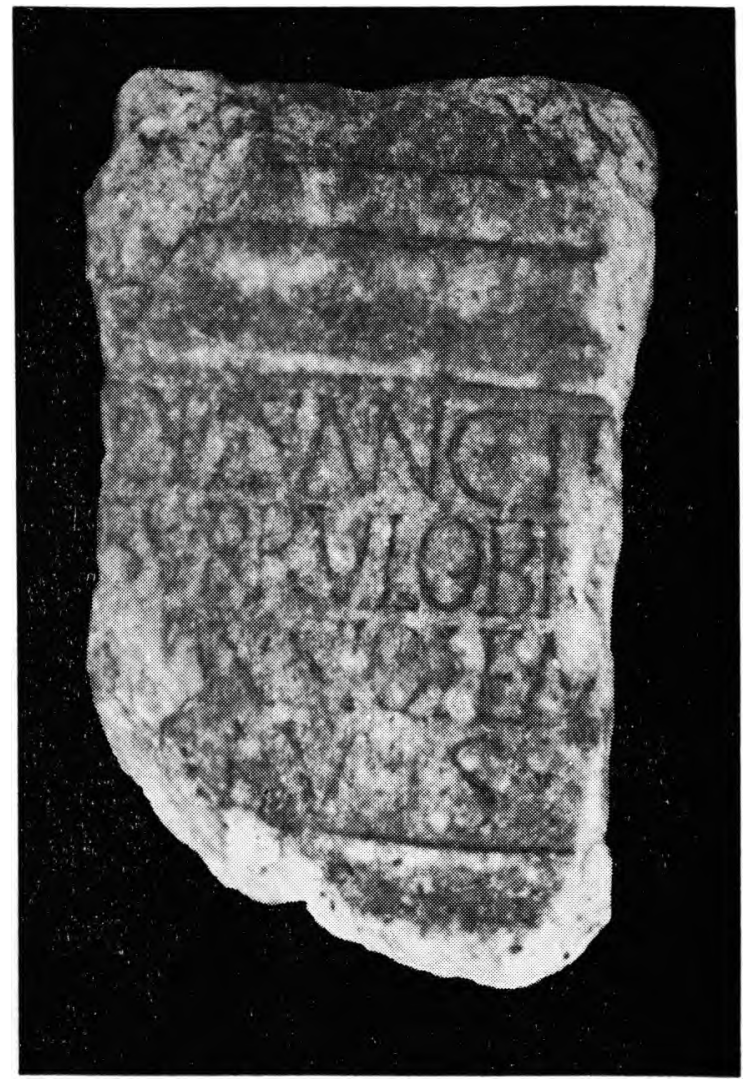

FIG. 4 - A ara à Deusa Santa Burrulobrigerse

\section{Endovellicus}

Divindade infernal, venerada num santuário em S. Miguel da Mota (Terena, Alandroal). É a divindade indígena com mais ex-votos no mundo romano.

IRCP, p. 800-805. Figs. 5 e 6.

\section{Jgaedo}

Patrono dos Igaeditani. Foi-lhe consagrada uma árula (achada junto da capela da Sr. ${ }^{\text {a }}$ do Almortão, Idanha-a-Nova) por Caetronia, Vitalis (filia).

$$
\text { DIP, p. 199-200. }
$$

Conimbriga, 26 (1987), 5-37 


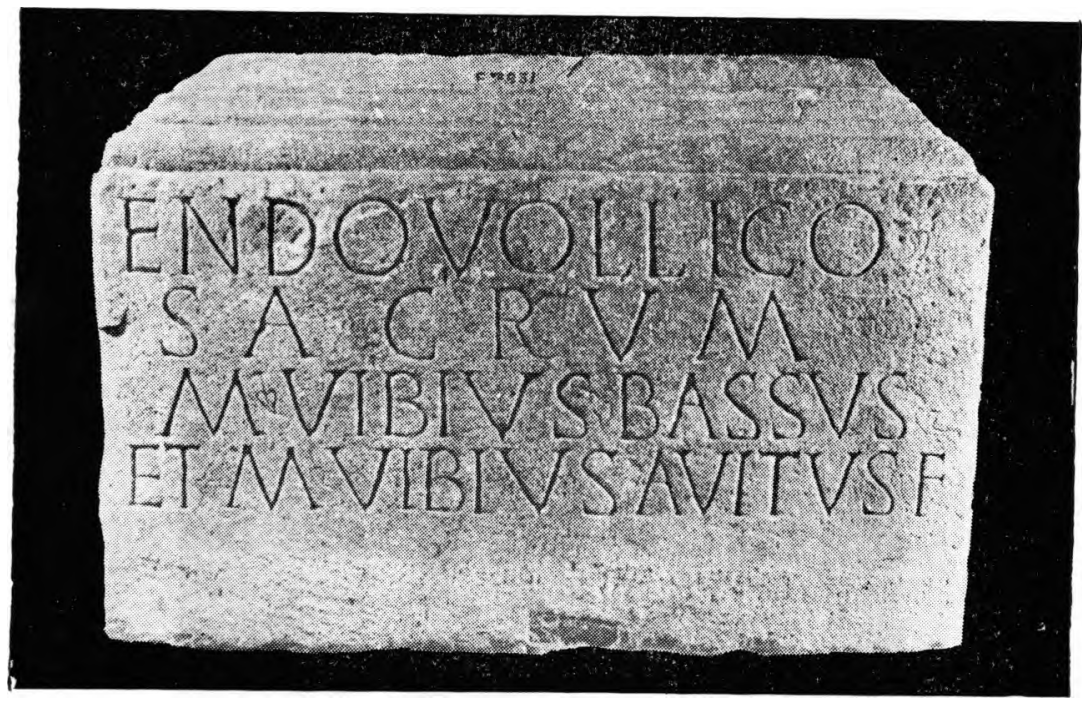

F IG. 5 -U m pedestal de estátua a Endovélico

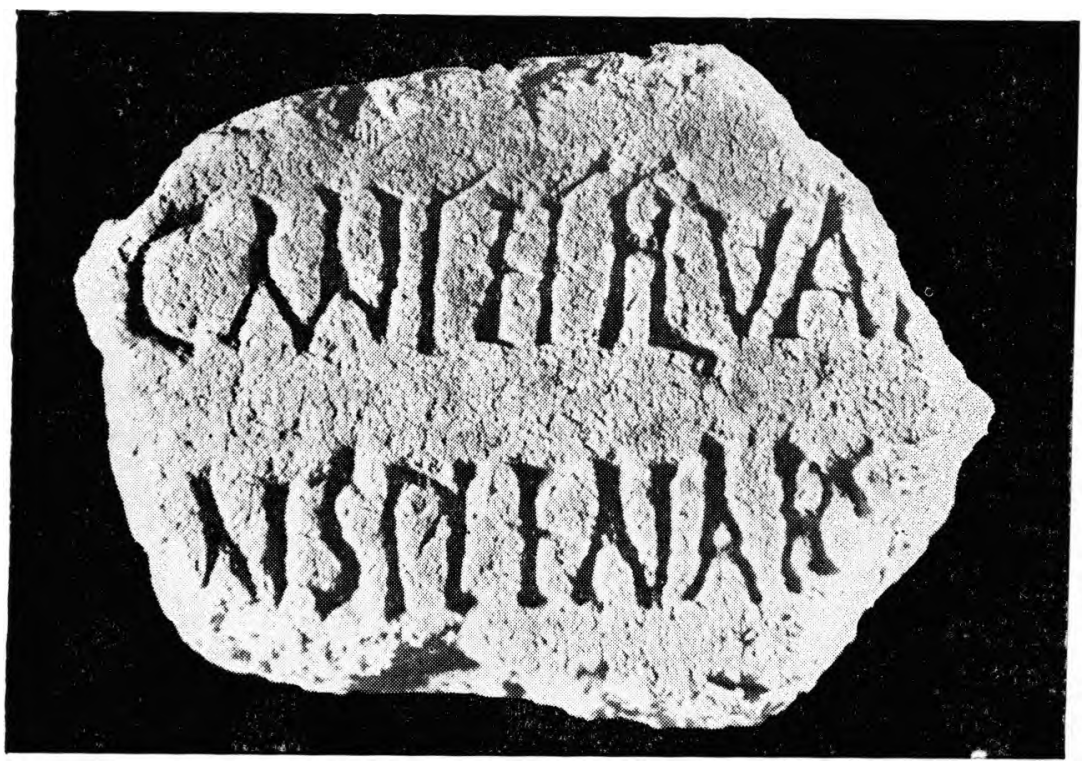

FIG. 6 - Fragmento dum eventual «cântico» a Endovélico (CIL II G333 b)

Conimbriga, 26 (1987), 5-37 


\section{Ilurbedae}

Duas aras the foram dedicadas, ambas procedentes dum poço de mina romana em Cova dos Ladrões, Alto das Cabeçadas (Alvares, Góis). Há outro testemunho, em território espanhol (Mangas 1971, p. 135-136).

DIP, p. 200-203.

l(ovi) Assaeco

Ara dedicada, em Lisboa, por M. Caecilius Caeno, a Júpiter, aqui honrado com um epíteto de carácter local.

DIP, p. 206-208.

Ioveai ( ?) Caeilobrigoi

M. Lourdes Albertos considera teónimos estes dois dativos do texto de Lamas de Moledo (Castro Daire). Caeilobrigus seria epíteto de Júpiter.

Albertos 1975, p. 58.

Iovi Repulsori

O epíteto Repulsor parece pròprio de uma zona determinada da Lusitânia, donde provêm vários testemunhos, o que nos leva a atribuir-lhe características indígenas.

IRCP 637-640.

\section{Issibaeo}

Divindade de características desconhecidas, homenageada na região de Miranda do Corvo por G. Claudius Maxsumus.

Brandão 1970, p. 77-83. DIP, p. 203-204.

\section{Iunoni Linteaicae ( ?)}

Possível epíteto local de Juno, que J. M. Garcia (1984, p. 61-62) relaciona com o linho. O monumento, procedente de S. Martinho (Castelo Branco), é dedicado por Talavius, Caburi f. 


\section{Laepo (não Caepo)}

Procedem da Quinta de S. Domingos (Pousafoles, Sabugal) as três árulas dedicadas a esta divindade, respectivamente, por Firmo, liberto de Sabina, por Tangino, filho de Lúcio Búcio, e por Basso, filho de Viriato. O texto gravado num penedo em Cabeço das Fráguas, da mesma freguesia, refere que a Laebo se ofereceu um porco: trata-se seguramente da mesma divindade (Tovar 1967). DIP, p. 153-154. FE 28.

\section{Laneane ( ?)}

Foi lido este teónimo (identificado já na região de Cáceres) num afloramento rochoso junto a Aldeia da Ponte (Sabugal). Terá algo a ver com a povoação de Lennium, ainda por localizar? (cf. Tovar 1976, 271). FE 99.

\section{Lares}

Por terem assumido um epíteto local, algumas destas divindades, classicamente romanas, podem revestir características indígenas :

- Lares A quites: o carácter único desta designação (ligada eventualmente ao culto das águas) é susceptivel de lhe atribuir conotação indígena. Encontrada em Conímbriga e considerada perdida, esta árula de pedra de Ançã foi recentemente identificada no Museu Nacional de Arqueologia e Etnologia por José Manuel Garcia (ver adiante, p. 48-49). Mede 18,5 x 7,5/6,2/8,2 x 6/3,5/5,5. O dedicante é G. C. Rufus. FC II, p. 28.

- Lares Cairienses: honrados por Celtienus, Canapi filius. Quinta da Nave Aldeã (Zebreira, Idanha-a-Nova). DIP, p. 210-211.

- Lares Conimbricae: a árula, incompleta, procedente de Conímbriga, é dedicada a Flávia Conímbriga e aos seus Lares. FC II, p. 28-30.

- L(ari?) Coutioso Longonaroso(P): ara procedente de Casais (S. João da Fresta, Mangualde) consagrada por Malgeinus, Leuri f., Arbuensis. FE 55.

- Lares Lubanci: divindades protectoras dos Lubancos ( ?), grupo social de contornos imprecisos que fazia parte dos Dovi- 
Iónicos. A placa que os refere, em nominativo ao contrário do que é habitual, encontrou-se em Conímbriga (Condeixa-a-Velha, Condeixa-a-Nova) e foi Albuius, Carnali f., quem a consagrou. FC II, p. 30-31.

- Lares Turolici: desapareceu o monumento corn que, em Freixo de Numão (Devesa, Meda), Catuenus, Docquirici filius, teria honrado estes Lares cujo epíteto se deve considerar, por isso, com reservas. DIP, p. 219-220.

\section{Liiruni}

Divindade, de características desconhecidas, adorada em Cavernães (Viseu), onde se encontraram quatro monumentos em sua honra: um perdeu-se; o segundo está no Museu de Grão Vasco, em Viseu; o terceiro guarda-se numa casa em AI velos, perto de Viseu; o quarto está em Vendas de Cavernães.

DIP, p. 226-230. Cfr. Untermann 1980, p. 422. FE 71.

\section{Mandiceo}

Deus de características desconhecidas a quem, em Sintra, Cássia Materna consagrou uma árula.

DIP, p. 232-233.

\section{Marti Boro}

Está na colecção epigráfica de Idanha-a-Velha a árula dedicada por L. C. O. a esta divindade da guerra que assume aqui, pelo epíteto, uma conotação local. Foi achada na serra de Monsanto (Idanha-a-Nova).

$$
\text { DIP, p. 233-234. }
$$

\section{Mercurio Augusto Aguaeco}

Divindade recordada num paralelepípedo mandado colocar nas termas de S. Pedro do Sul por Magius Reburrus e Victoria Victorilla em honra de seu filho, Magius Saturninus. Mercúrio assume, aqui, além da relação com o imperador, um carácter tópico de divindade termal.

Brandão 1959, p. 229-264. 


\section{Mercurio Esibraeo}

Divindade que poderá figurar numa árula achada na capela de Santiago (Medelim, Idanha-a-Nova). Pelo epíteto, relacionar-se-á com Bandi Isibraiegui.

Garcia 1984, p. 65-66.

\section{Munidi ( ?) Icaed(itanae)}

É a existência do texto de Talavan (ILER 884) dedicado a Munidi Eberobrigae Toudopalandaigae que nos permite manter a interpretação MVN[I]DI . ICAED(itanae) da árula de Idanha-a-Velha ou Monsanto (Idanha-a-Nova). De facto, como - na sequência das nossas dúvidas - A. Rodríguez Colmenero demonstrou recentemente («Veleia», 2-3, 1985-6, p. 343-4), na inscrição de Chaves (ILER 883) não é esse o teónimo mencionado. E o monumento de Idanha encontra-se fracturado a seguir ao $\mathrm{N}$. Não concordamos, no entanto, com a hipótese de 1er MVN(imentum). DI(o).ICAED[0], «monumento ao deus Igaedo»: $\left.1 .^{\circ}\right)$ porque, tratando-se de uma ara, é forçada a utilização do vocábulo monumentum; $2 .^{\circ}$ ) porque seria formulário inusitado na epigrafia da Lusitânia; $3 .^{\circ}$ ) porque se nos afigura estranha e indocumentada a interpretação $\mathrm{DI}(\mathrm{o})$.

CIL II 424, que se encontra numa penedia junto do castelo de Celorico da Beira, será também dedicatória a Munis feita por um filho de Malgueino: cf. Curado, 1985, p. 641-3.

Tratar-se-ia, pois, de uma divindade tutelar.

DIP, p. 237-240.

\section{Nabia}

A esta divindade peninsular foram dedicadas dezasseis epígrafes, uma das quais na Lusitânia portuguesa - Roqueiro (Pedrógão Pequeno, Sertã) - mandada gravar por Cicero, Manci (filius). Segundo José L. Melena, que fez um estudo exaustivo sobre a divindade (1984, p. 233-260), ela deve considerar-se, de preferência, "uma deusa indígena dos vales arborizados, dos bosques e dos montes, como a Diana latina, vales que no seu fundão poderiam acolher a presença dum rio, o que explicaria o hidrónimo 
[Navia] e a caracterização dada a Nabia e, de modo particular, a sua vinculação com divindades aquáticas» (p. 245).

DIP, p. 240-243. Cf. também Garcia (B.) 1985, p. 282 n. 12.

Ocrimirae

Divindade tutelar duma ribeira fria homenageada, em Marvão, por Júlia Saturisca.

IRCP 610 e p. 806.

Paisicaico

O vocábulo, gravado num penedo nas Corgas Roçadas, entre Covas e Vermilhas (Vouzela), pode ser o nome da divindade aí venerada.

DIP, p. 256-257.

\section{Peinticis}

Invocação, insegura, das divindades eventualmente referidas no texto, de difícil interpretação, gravado num rochedo do Castro dos Três Rios, entre Fail (Viseu) e Parada de Gonta (Tondela). Poderá ter sido L. Manlius, cidadão romano da tribo Aemilia, que mandou gravar a epígrafe.

DIP, p. 257-258.

\section{Quangeio Tanngo}

Acompanhado pelo epíteto Tanngus, o deus é venerado em Nisa por Lupus, Lanci filius (IRCP 641). No entanto, esta epígrafe permitiu a correcção da leitura de outros monumentos dedicados à mesma divindade: um em Malpartida de Plasencia (fora da Lusitânia portuguesa) e dois em Penamacor - FE 26 e corrigenda; IRCP, p. 806; Garcia 1985, p. 23-32. Mais testemunhos em Ribeira da Nave (Sabugal) - FE 100; um outro, provável, em Nisa (FE 103); finalmente, também se poderá 1er este teónimo numa ara de Capinha (Fundão) - cf. FE 103, nota 2. 
Remetibus Aug(ustis)

Divindades registadas numa placa encontrada nas termas de Conímbriga, razão pela qual se lhes atribui um carácter aquático.

FC II, p. 38-40.

Reva

Divindade tutelar de que, na Península, se encontraram diversos testemunhos, com epítetos diferentes. São os seguintes os que provêm da Lusitânia portuguesa:

- A Reva, acompanhado por um epíteto que desapareceu, se diz no texto de Cabeço das Fráguas (Pousafoles, Sabugal) que foi oferecido um touro semental. Tovar 1967.

- Foi possivelmente consagrado a Reva, acompanhado de um epíteto começado por $\mathrm{C}$, a ara encontrada em S. Eufémia (Pinhel), dedicada por Casabius, Burrilli filius. FE 17 e corrigenda.

- No concelho de Idanha-a-Nova, a divindade tinha um epíteto local que surge grafado (no dativo) Langanidaegui (em Medelim) e Langanitaeco (em Proença-a-Velha). Esse mesmo epíteto - Langanid(aeco ?) - surge perto de Alcains, Castelo Branco (Garcia 1984, p. 69) e é possível que outra árula procedente de Medelim também apresentasse o mesmo epíteto, hoje desaparecido (Garcia 1984, p. 67-68). Os dois primeiros monumentos estão na colecção epigráfica de Idanha-a-Velha; os outros dois guardam-se no Museu de Castelo Branco. O mais significativo de todos é a placa de Proença-a-Velha, dedicada por Lucanus, Adiei f., por trazer a expressão hostia deliganda, relacionada decerto com o rito sacrificial. DIP, p. 263-268.

\section{Salquia}

Embora o vocábulo apresente pontuação interliteral, numa ara que se encontra no Museu de Gouveia, é aceitável a identificação aí deste teónimo. O monumento foi dedicado por Reburrus, Talabi f.

Curado 1985, p. 648-9. 


\section{Sancto Runesio Cesio}

Procede dos arredores de Évora a árida consagrada a esta divindade cujas atribuições bélicas a etimologia do seu nome parece confirmar. Fig. 7.

IRCP 374 e p. 806.

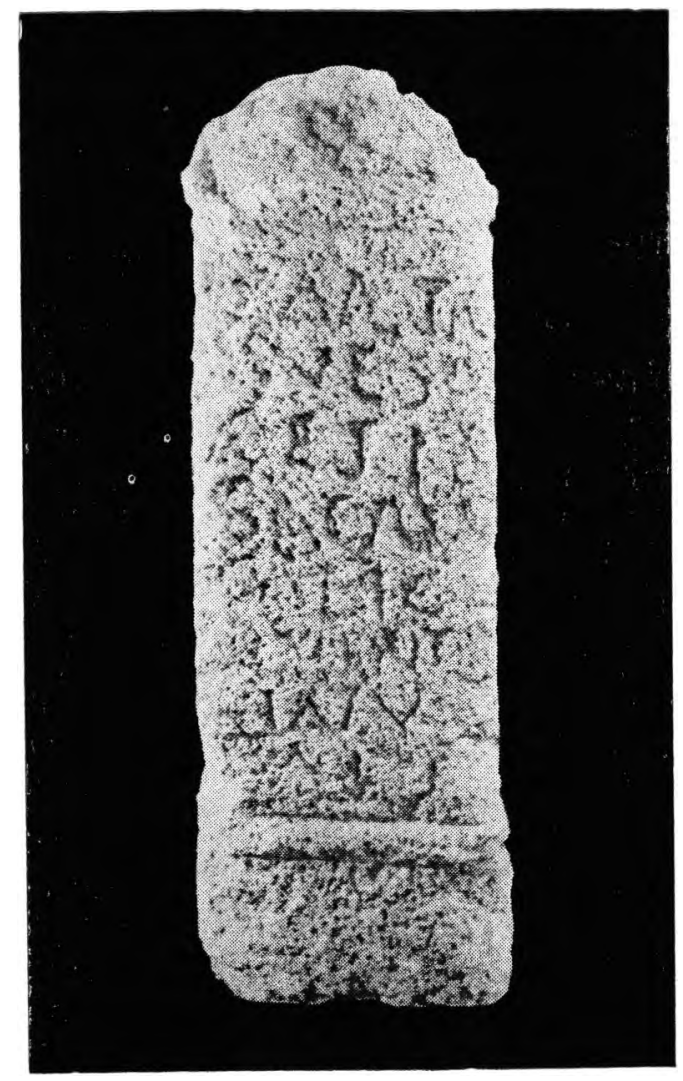

FIG. 7 - A árula a Sanctus Painesus Cesius

\section{Tabudico}

Divindade, de características desconhecidas, honrada em Murtede (Cantanhede) numa coluna oferecida por C. Fabius Viator, 
que se guarda no Instituto de Arqueologia da Faculdade de Letras de Coimbra.

DIP, p. 274-276.

\section{Togae Almae}

Encontra-se, de facto, no Museu de Marvão a ara consagrada a esta divindade benfazeja por Novela, liberta de Ânia. Outros três monumentos lhe foram dedicados na Península: cf. FE 49.

IRCP 611 e p. 806.

\section{Trebaruna}

1. Na inscrição do penedo de Cabeço das Fráguas, refere-se a oferta sacrificial de uma ovelha com um ano a Trebaruna. Tovar 1967.

2. Do Fundão procede uma ara, hoje no Museu Nacional de Arqueologia e Etnologia, dedicada por Toncius, Toncetami f., soldado igeditano. DIP, p. 288-291. Fig. 8.

3. Encontrou-se na Quinta de Alverca (Lardosa, Castelo Branco) a ara, hoje guardada no Museu de Castelo Branco, dedicada (verosimilmente) por Voconus, Voconis f. O teónimo é, aqui, grafado com O e dois NN: Trebaronne. Garcia 1984, p. 73-74.

4. É de interpretação difícil o texto em honra de Trebaronna gravado numa ara achada em Cabeço dos Tiros (Penha Garcia, Idanha-a-Nova). Parece atestar a existência de sacerdotes. Garcia 1984, p. 71-72.

5. A ara que encontrámos em S. Domingos de Rana (Cascais) foi oferecida por Tito Curiácio Rufino Triborunni. Consideramos que se trata de mais uma variante deste teónimo. FE 59.

\section{Trebopala}

Nome da divindade a que, segundo o texto sacrificial de Cabeço das Fráguas (Pousafoles, Sabugal), se ofereceu uma ovelha.

Tovar 1967. 


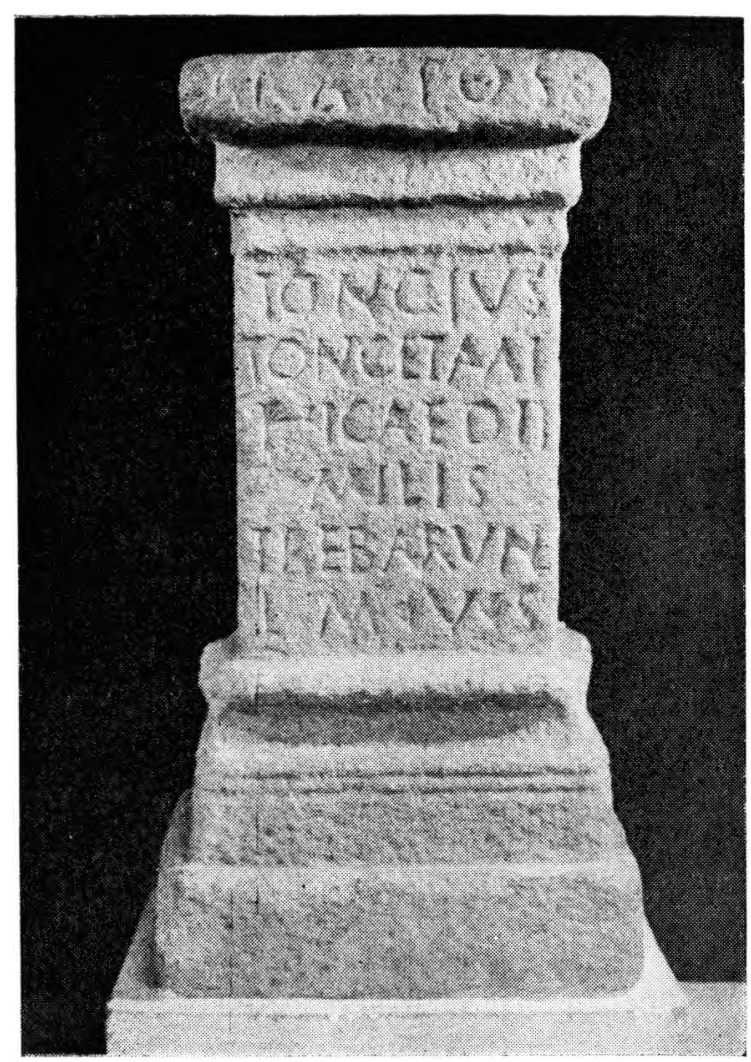

Fig. 8 - Ara a Trebaruna

\section{$\operatorname{Vaseco}(?)$}

Parece-nos que é de manter duvidoso este eventual teónimo, de significado desconhecido. Tivemos ocasião de analisar e fotografar a árula $(18 \times 7 \times 6 \mathrm{~cm})$ procedente de Soure e que efectivamente se encontra na Academia das Ciências de Lisboa (Inventário: n. ${ }^{\circ}$ 245). De calcário oolítico, rudemente moldurada nas quatro faces, com toros e fastígio, linhas auxiliares bem marcadas, apresenta no campo epigráfico polido o seguinte texto esgrafi-

Conimbriga, 26 (1987), 5-37 
tado: B MER\#VASECO / MARI/NIANV/S ANIM/O LEBE/S (sic) PONO 7 MER / MA. Se interpretarmos b(ene)mer(enti) na linha 1 e considerando Marinianus o nome do dedicante, o teónimo será de facto Vaseco. Fig. 9.

DIP, p. 296-7. Cf. J. Cardim Ribeiro in «Conimbriga», XXIII, 1989.

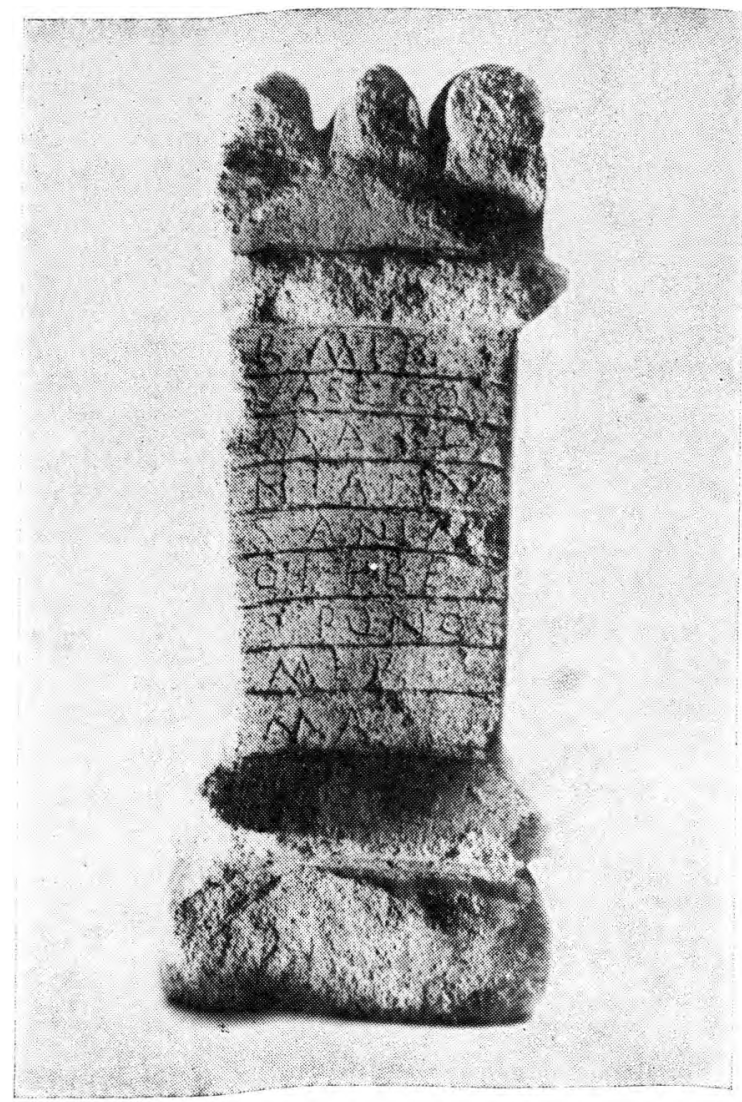

FIG. 9-A árula a Vasecus 


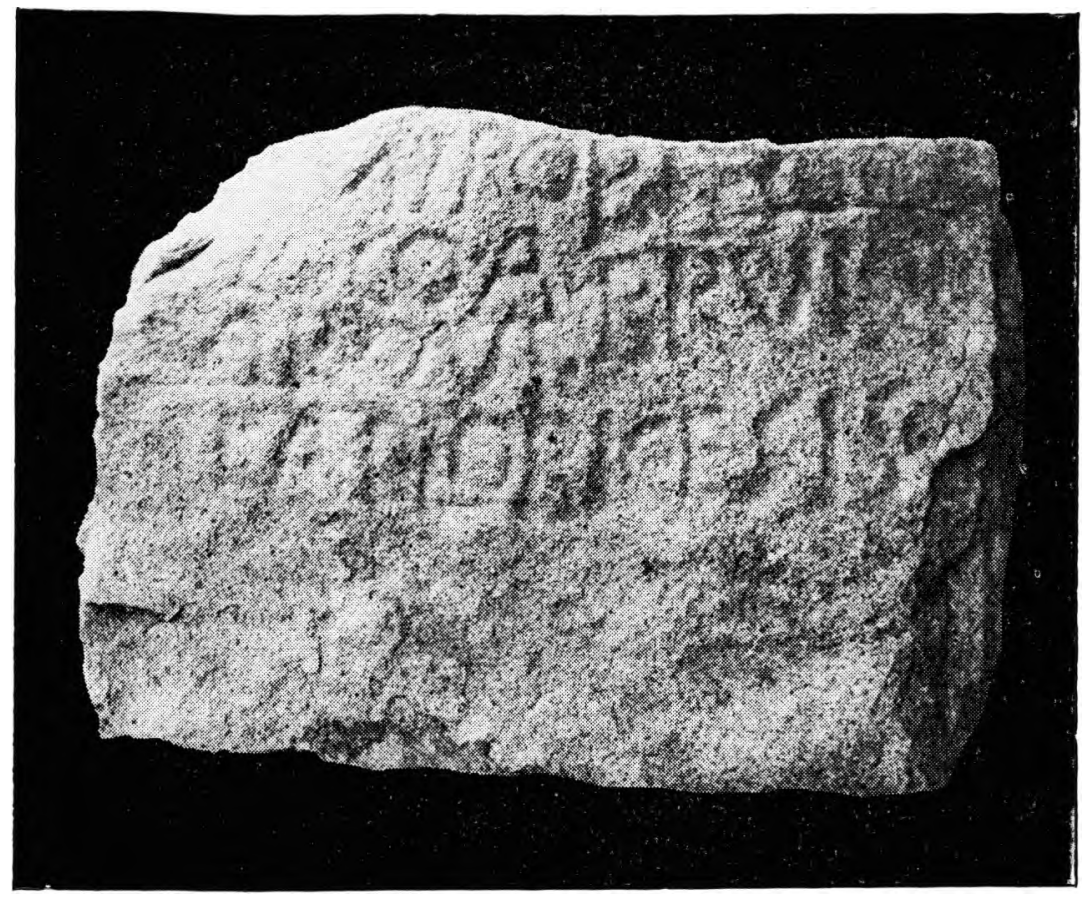

FIG. 10 - (Ver nota 1 do apêndice)

\section{BIBLIOGRAFIA}

(Citámos apenas a bibliografîa mais actualizada, designadamente quando referia a anterior)

Albertos Firmat (M. ${ }^{\mathrm{a}}$ de Lourdes), Organizaciones Suprafamiliares en la Hispania Antigua, Valladolid, 1975.

------, A propòsito de algunas divinidades lusitanas, «Symbolae Ludovico Mitxelena Septuagenario Oblatae», Vitoria, 1985, p. 469-474.

------, Notas a los trabajos del Prof. Cor ominas, presentados al I Coloquio sobre Lenguas y Culturas Prerromanas de la Península Ibérica, Salamanca 1974, «Actas del III Coloquio sobre Lenguas y Culturas Paleohispanicas», Salamanca, 1985 , p. 503-505.

Almeida (D. Fernando de), Mais divindades lusitanas do grupo «band», «Revista da Faculdade de Letras de Lisboa», 9, 1965, p. 19-31. 
Brandão (D. Domingos de Pinho), Inscrições romanas do Balneum de Lafões, «Beira Alta», 19, 1959, p. 229-26 4.

-----, Issibaeus - uma nova divindade do panteão lusitano-romano, «Actas das

I Jornadas Arqueológicas», Lisboa, 1970, p. 77-83.

Corominas (Joan), Acerca de algunas inscripciones del Noroeste, "Actas del I Coloquio sobre Lenguas y Culturas Prerromanas de la Península Ibérica», Salamanca, 1976, p. 363-385.

Correia, (Alberto), Alves (Alexandre), e Yaz (João L. Inés), Castro Daire. Castro Daire, 1986.

Curado (Fernando Patrício), Epigrafia das Beiras (Notas e correcções - 1), «Beira Alta», 44 (4), 1985, p. 641-655.

DIP = Encarnação (José d'), Divindades Indigenas sob o Domínio Bomano em Portugal. Lisboa, 1975.

EnCARnaÇão (José d'), Urna árula a Banduaetobrigus - Additamentum, «Conimbriga», 15, 1976, p. 139-146.

-----, Epigrafia Bomana do Nordeste Alentejano - Nisa, Torre de Palma e Silveirona, «Conimbriga», 16, 1977, p. 59-82.

-----, Belver ao Tempo dos Bomanos — a população e as suas crenças. Portalegre, 1984. (De colaboração com Rogério P. Carvalho).

FC II = Étienne (R.), Fabre (G.) e Lévêque (P. et M.), Fouilles de Conimbriga II - Épigraphie et Sculpture, Paris, 1976.

$\mathrm{FE}=$ «Ficheiro Epigráfico» (suplemento de «Conimbriga»), Coimbra. (Indica-se o número da inscrição).

Garcia (J. M.), Contribuição para a compreensão das divindades do "Grupo Band» - uma nova ara, «Conimbriga», 15, 1976, p. 147-150.

------, Epigrafia lusitano-romana do Museu Tavares Proença Junior. Castelo Branco, 1984.

------Quangeio deus lusitano, «História», 76, Fevereiro de 1985, p. 23-32.

García y Fernández-Albalát (Blanca), Las divindades indígenas de la Hispania Prerromana - En pos de una metodologia, «Trabalhos de Antropologia e Etnologia», 25 (2-4), 1985, p. 275-283.

IRCP = EnCARnação (José d'), Inscrições Bomanas do Conventus Pacensis, Coimbra, 1984.

Leitão (Manuel) e Barata (Luís), Inscrições romanas de Bemposta, "Trabalhos de Antropologia e Etnologia», 23, 1980, p. 627-634.

LE Roux (Patrick), L'armée romaine et Vorganisation des provinces ibériques d'Auguste à l'invasion de 409, Paris, 1982.

Mangas (Júlio), Nuevas inscripciones latinas de Salamanca y su provincia, «Archivo Español de Arqueologia», 44, 1971, p. 127-136.

Melena (José L.), Un ara votiva romana en El Gaitán, Cáceres, «Veleia», 1, 1984, p. 233-260.

Tovar (A.), L'inscription du Cabeço das Fráguas et la langue des Lusitaniens, «Études Celtiques», 11, 1967, p. 237-268.

------, Iberische Landeskunde-Band 2, Lusitanien. Baden — Baden, 1976.

Conimbriga, 26 (1987), 5-37 
Unter mann (J.), Recensão a Divindades Indígenas... «Beitrage zur Namensforschung», 15,1980, p. 421-424.

------Los teónimos de la región lusitano-gallega como fuente de las lenguas indigenas, «Actas del III Coloquio sobre Lenguas y Culturas Paleohispanicas», Lisboa, 5-8 Noviembre 1980), Salamanca, 1985, p. 343-363.

V AZ (João L. Inés), Inscrições romanas do Museu do Fundão, "Conimbriga», 16,1977 , p. 5-31.

Fotos

De Guilherme Cardoso, à excepção das n.os 2 e 9, que são de Delfim Ferreira. 